\title{
Családi halmozódást mutató papillaris pajzsmirigy-carcinoma
}

\author{
Tóth Géza dr. ${ }^{1}$ - Győry Ferenc dr. ${ }^{2}$ - Bodor Miklós dr. ${ }^{3}$ \\ Molnár Csaba dr. ${ }^{4}$ - Nagy V. Endre dr. ${ }^{3}$ \\ ${ }^{1}$ Szent Lázár Megyei Kórház, Endokrinológia, Salgótarján \\ ${ }^{2}$ Debreceni Egyetem, Általános Orvostudományi Kar, Sebészeti Intézet, Debrecen \\ ${ }^{3}$ Debreceni Egyetem, Általános Orvostudományi Kar, Belgyógyászati Intézet, Endokrinológia Tanszék, Debrecen \\ ${ }^{4}$ Debreceni Egyetem, Általános Orvostudományi Kar, Pathologiai Intézet, Debrecen
}

\begin{abstract}
A differenciált pajzsmirigydaganatok körébe tartozó papillaris és follicularis carcinomákat együttesen nem medullaris pajzsmirigyráknak nevezzük, melyek az összes pajzsmirigy-carcinoma 90\%-át teszik ki. Ezen daganatok 5-10\%-a családi halmozódást mutat, és csak elenyésző hányaduk, mintegy 3-5\%-uk köthető monogénes öröklődést mutató tumorszindrómához. Az összes többi familiaris nem medullaris pajzsmirigy-carcinoma hátterében egyértelmú genetikai eltérés nem észlelhető. A családi halmozódást mutató nem medullaris pajzsmirigyrákok viselkedése, agresszivitása és kimenetele rosszabb a sporadikus formáénál. Tizenhét évvel ezelőtt, az akkor 45 éves nőnél derült fény pajzsmirigy szolid göbjének hátterében papillaris carcinomájára. Mútétet és radiojód-ablatiót követően levotiroxinkezelés mellett azóta tumormentes. Egy éve 41 éves leányánál multinodularis struma mútéte során tokinfiltrációval és nyaki nyirokcsomóáttétekkel járó papillaris carcinoma igazolódott. 39 éves másik leányánál szűrővizsgálatot követően derült fény multiplex pajzsmirigygöbjeire. A mútét során multiplex papillaris daganatot találtunk tokáttöréssel, érinvázióval, valamint nyaki nyirokcsomóáttétekkel. Totális thyreoidectomiára, valamint centrális nyaki blokkdissectióra került sor. Ezt követóen radiojód-terápiát, majd levotiroxint kapott. Esetünkkel szeretnénk felhívni a figyelmet a familiaris nem medullaris pajzsmirigy-carcinomák jelenlétére, azok agresszívebb természetére és emiatt a családszürés, valamint a kezelési stratégia megválasztásának fontosságára.
\end{abstract}

Orv Hetil. 2020; 161(43): 1849-1854.

Kulcsszavak: familiaris nem medullaris pajzsmirigy-carcinoma, családi halmozódás, tumorszindróma

\section{Familial papillary thyroid cancer}

Differentiated thyroid cancer, also called non-medullary thyroid cancer, includes papillary and follicular carcinomas. Up to $10 \%$ of these tumors cluster in families, and $3-5 \%$ of these cases present as part of rare tumor syndromes. In the majority of the familial cases, no genetic background can be detected. Familial non-medullary thyroid cancer is more aggressive and its prognosis is worse than that of the sporadic form. A 45-year-old female patient was operated 17 years ago for papillary carcinoma. After radioiodine ablation, she has been free of tumor during follow-up visits. One year ago, one of her daughters had surgery because of multinodular goiter. On histology, papillary carcinoma was found with capsule invasion and lymph node metastases in the neck region. The other daughter underwent thyroid screening because of the family history. After fine-needle aspiration biopsy, findings were characteristic of papillary cancer, and total thyroidectomy followed. In 3 nodules, papillary thyroid cancer with capsule- and vessel invasion, and metastases in lymph nodes of the neck region were found. After radioiodine treatment, she is on suppressive levothyroxine therapy. Clustering of papillary cancer cases in a family may be familial non-medullary thyroid cancer. Its more aggressive nature compared to sporadic cases warrants carefully selected treatment strategy and early screening of family members.

Keywords: familial non-medullary thyroid cancer, family accumulation, tumor syndrome

Tóth G, Győry F, Bodor M, Molnár Cs, Nagy VE. [Familial papillary thyroid cancer]. Orv Hetil. 2020; 161(43): 1849-1854.

(Beérkezett: 2020. május 4.; elfogadva: 2020. május 22.) 


\section{Rövidítések}

APC $=$ adenomatosus polyposis coli $;$ ATPO $=$ antithyreoidea peroxidáz; $\mathrm{CT}=$ (computed tomography) számítógépes tomográfia; FAP = familiaris adenomatosus polyposis; FNAB = (fine-needle aspiration biopsy) aspirációs vékonytú-biopszia; FNMTC $=$ (familial non-medullary thyroid carcinoma) familiaris nem medullaris pajzsmirigy-carcinoma; $\mathrm{fT} 3=$ (free triiodothyronine) szabad trijód-tironin; $\mathrm{fT} 4=$ (free thyroxine) szabad tiroxin; FTC = (follicular thyroid carcinoma) follicularis pajzsmirigy-carcinoma; GWAS = (genome-wide association study) teljesgenom-asszociációs vizsgálat; $\mathrm{MNGl}=$ (multinodular goiter 1 ) multinodularis golyva- $1 ; \mathrm{mRNS}=($ messenger $)$ hírvivô RNS; NMTC = (non-medullary thyroid carcinoma) nem medullaris pajzsmirigy-carcinoma; PRKARlA $=$ (cyclic adenosine monophosphate [cAMP]-dependent protein kinase type I regulatory subunit alpha) ciklikus adenozin-monofoszfáttól (cAMP-) függő proteinkináz A-1A szabályozó alegység; PTC $=$ (papillary thyroid carcinoma) papillaris pajzsmirigy-carcinoma; PTEN = (phosphatase and tensin homolog) foszfatáz- és tenzinhomológ; RNS $=$ ribonukleinsav; $S P E C T=($ single-photon emission computed tomography) egyfoton-emissziós számítógépes tomográfia; $\mathrm{TCO}=($ thyroid cell oxyphilia $)$ pajzsmirigysejt-oxyphilia; $\mathrm{TSH}=$ (thyroid-stimulating hormone) pajzsmirigy-stimuláló hormon; TRAK = (thyrotropin receptor antibodies) TSH-receptor elleni antitestek; USA = United States of America; $\mathrm{WHO}=$ (World Health Organization) Egészségügyi Világszervezet; WRN = Werner syndrome helicase
A pajzsmirigyrák a malignus endokrin daganatok leggyakoribb képviselője. Az összes pajzsmirigydaganat közel 90\%-a differenciált pajzsmirigy-carcinoma. Ezen belül a papillaris forma $80-85 \%$ körüli, a többi follicularis. Ezen daganatokat nem medullaris pajzsmirigy-carcinomának (NMTC) is nevezzük. A nem medullaris pajzsmirigyrákok 5-10\%-a családi halmozódást mutat (FNMTC), mely daganatok 3-5\%-a meghatározott genetikai eltéréssel jár, és valamely tumorszindróma részjelensége. Ezek a Gardner-szindróma, a familiaris adenomatosus polyposis (FAP), a Werner-szindróma, a Carney-komplex és a Cowden-szindróma [1-4] (1. ábra). A többi FNMTC hátterében egyértelmü és egységes genetikai rendellenesség nem ismert. Különböző vizsgálatok számos lehetséges, hajlamosító mutációt, polimorfizmust találtak, de a tumorszindrómákhoz hasonló egységes eltérést nem. A genetikai elváltozásokon kívül egyéb környezeti hatások is ismertek, melyek szerepet játszhatnak egy családon belül halmozottan előforduló pajzsmirigyrák kialakulásában. Az ionizálósugárzás-expozíció papillaris carcinomára hajlamosít, míg a jódhiány, illetve a jódellátottság zavara esetén a follicularis daganatok relatív aránya emelkedik. Az endémiás golyvával sújtott területen élők körében papillaris tumor kialakulásával lehet számolni [5]. A familiaris és a sporadikus nem medullaris pajzsmi-

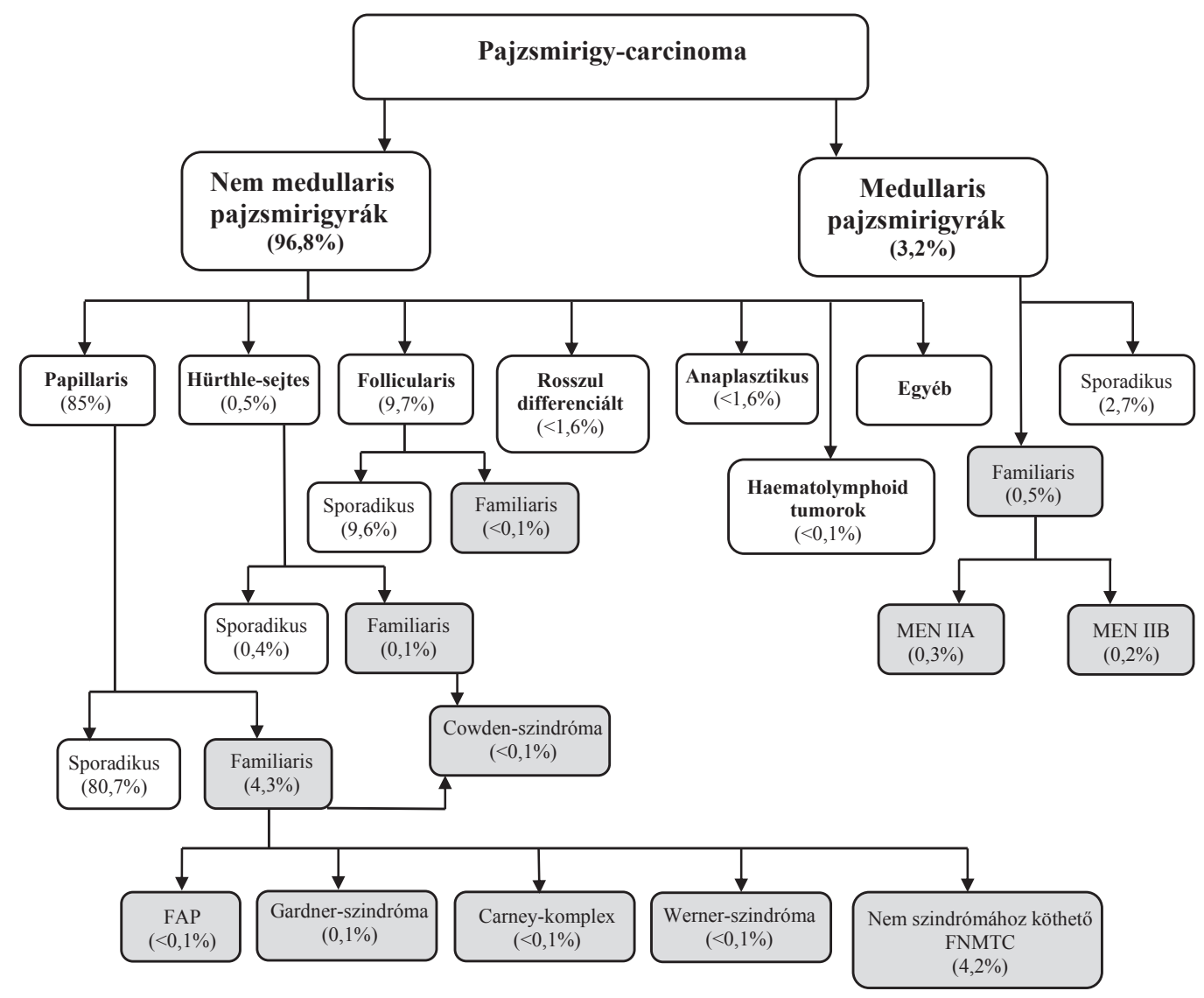

1. ábra $\quad$ A pajzsmirigydaganatok klasszifikációja. Az öröklődő formák szürke alapon vannak feltüntetve. A 2019-es WHO-klasszifikáció nyomán [4] $\mathrm{FAP}=$ familiaris adenomatosus polyposis; FNMTC = familiaris nem medullaris pajzsmirigyrák; MEN = multiplex endokrin neoplasia; $\mathrm{WHO}=$ Egészségügyi Világszervezet 
rigy-carcinomák időbeli megjelenése, súlyossága, lefolyása, invazivitása, metasztatikus hajlama, túlélése eltérő. Az FNMTC agresszívebb lefolyású, emiatt a kezelési stratégia megválasztása nagyobb odafigyelést igényel [1-3, 6-9]. Az alábbiakban egy család három tagjának (anya és két leánya) esetét mutatjuk be. Mindhárom betegnél a pajzsmirigy göbös elváltozásának hátterében jól differenciált papillaris carcinoma igazolódott.

\section{Esetismertetés}

Tizenhét évvel ezelőtt, az akkor 45 éves nőbetegnél egy gócból kiinduló papillaris pajzsmirigydaganatot találtak. A tumor $20 \mathrm{~mm}$ átmérőjü volt, sem érinváziót, sem tokáttörést nem okozott. Regionális vagy távoli áttéteket nem találtak. Komplettáló pajzsmirigymútétet követően radiojód-ablatióban részesült. Az ajánlásoknak megfelelő adagban levotiroxint kap, tumormentes. Egy éve 41 éves leánygyermekénél szintén papillaris pajzsmirigy-carcinomát diagnosztizáltak. Lányánál már két gócban is tumoros elváltozást igazoltak, melyek közül az egyik 9 mm-es, a másik 16 mm-es volt. Ezen elváltozás tokérintettséget is mutatott, valamint a regionális nyirokcsomókba áttétet is adott. Emiatt második ülésben teljes pajzsmirigy-eltávolításra került sor, centrális nyaki nyirokcsomó-dissectióval. Betegünk panasz és tünet nélkül jelentkezett, édesanyja és nővére tumoros betegségétől tartva kérte pajzsmirigystatusának felmérését. Ultrahangvizsgálat során a jobb lebenyben 18 mm-es és 9 mm-es, az isthmusban 12 mm-es, szabálytalan körvonalú, mikromeszesedéseket tartalmazó göböket találtunk, míg a bal lebenyben egy 42 mm-es, 'halo' jellel övezett, kissé echódúsabb göböt. Az aspirációs vékonytü-biopszia (FNAB) során a nagy, bal oldali göböt benignusnak véleményezték, míg a jobb oldali domináns göbből nyert minta papillaris carcinomára utalt. A laborvizsgálatok negatív eredményt adtak: TSH: 3,45 mU/1 (0,27-4,2); fT4: 14,6 pmol/1 $(9,0-24,0)$; fT3: $3,67 \mathrm{pmol} / 1(2,8-$ 7,4); ATPO: 8,0 IU/ml $(<34,0)$; TRAK: 0,73 IU $/ 1$ $(<1,75)$; tireoglobulin: $45,6 \mathrm{mg} / \mathrm{l}(1,4-78)$; anti-tireoglobulin: $58,2 \mathrm{mg} / \mathrm{l}$ (1,4-78); kalcitonin: $1,5 \mathrm{pg} / \mathrm{ml}$ $(0-11,5)$. Tekintettel az FNAB-leletre és a családi anamnézisre, totális thyreoidectomiát, valamint centrális nyaki blokkdissectiót végeztünk. Szövettani vizsgálat során mindkét jobb oldali és az isthmicus göb papillaris carcinomának bizonyult, tokáttöréssel, érbetöréssel, valamint 2/14 nyaki nyirokcsomóáttéttel. A nagy, bal oldali göb benignus volt. Radiojód-kezelést adtunk $3700 \mathrm{MBq}$ dózisban. A harmadik napon elvégzett posztterápiás egésztest-SPECT-CT sem a pajzsmirigy várható vetületében, sem egyéb területen nem mutatott kóros radiofarmakon-dúsulást. Levotiroxint kap a protokollnak megfelelő adagban. A betegeknél elvégzett kolonoszkópia, hasi és emlőultrahang-, nőgyógyászati szưrővizsgálat negatív eredményt adott, valamint a tumorszindrómákra jellegzetes klinikai tünetek is hiányoztak. A harmadik leánytestvér kivizsgálása külföldi laboratóriumban folya- matban van. Eddigi információnk szerint a pajzsmirigy bal lebenyében mikromeszesedést is tartalmazó, 'halo' jellel övezett $11 \mathrm{~mm}$-es, echószegény göböt találtak. Az FNAB kolloidban gazdag háttérben szabályos follicularis szerkezetet mutató sejteket ábrázolt, malignus jelek nélkül.

\section{Megbeszélés}

A pajzsmirigy rosszindulatú elváltozásai az összes malignus daganat 2-4\%-át teszik ki, és az endokrin mirigyek carcinomái közül a leggyakoribbnak számítanak. Az utóbbi két évtizedben a pajzsmirigyrák előfordulása folyamatosan növekszik, az USA-ban 15 év alatt több mint a kétszeresére [2, 10], Dél-Koreában 1999 és 2007 között az ötszörösére nőtt az incidenciája. Míg 1999-ben százezer lakosra 7,2 új eset jutott, addig ez a szám 2007re 38,1-re emelkedett [6]. 2018-ban a WHO szerint 567233 új pajzsmirigyrákos esetet dokumentáltak a világon, és a tumorspecifikus halálozás 41071 volt [11]. Magyarországon az 1980-as években észlelt évi 240 új megbetegedés helyett az utóbbi években 450-500 új esettel kell számolni. Az incidencia növekedésének legvalószínúbb oka a vizsgálati módszerek, elsősorban az ultrahangvizsgálatok széles körü alkalmazása [10]. A betegség nókön háromszor gyakoribb, mint férfiakon. $\mathrm{Az}$ éves incidencia férfiakon 1,2-2,6 és nőkön $2-3,8 / 100000$ lakos. Jelen esetünkben is mindhárom érintett páciens nő volt [1].

Az összes pajzsmirigydaganat közel 90\%-a differenciált pajzsmirigy-carcinoma. A differenciált pajzsmirigydaganatok képviselői, a papillaris és a follicularis carcinoma a pajzsmirigy follicularis epithelsejtjeiből indul ki. Az NMTC-k 5-10\%-a családi halmozódást mutat. Ezek 3-5\%-a monogénes öröklésmenetet mutató tumorszindrómához köthető [2-4]. A familiaris adenomatosus polyposis autoszomális domináns öröklődést mutató betegség, mely az 5 . kromoszóma hosszú karján a 21 -es lókuszon (5q21) elhelyezkedő APC (adenomatosus polyposis coli) tumorszuppresszor gén mutációjának tulajdonítható. A Gardner-szindróma a FAP olyan variánsa, ahol a familiaris adenomatosus polyposis mellett epidermoid cysták, desmoid tumorok, osteomák is megfigyelhetők. A pajzsmirigyrák előfordulása 1-12\%. Jellemzően papillaris pajzsmirigy-carcinoma (PTC) alakul ki, mely gyakran multifokális, és fiatal nőkben gyakoribb. A Cowden-szindróma szintén autoszomális dominánsan öröklődik. Itt leginkább a 10. kromoszóma hosszú karján a 22-23-as lókuszon (10q22-23) elhelyezkedő PTEN-gén mutációja a betegség okozója. A betegségre multiplex hamartomák, valamint a veséből, emlőből, vastagbélból, endometriumból kiinduló epithelialis tumorok jelenléte jellemző. A pajzsmirigy érintettségének gyakorisága 10\%-ra tehető. Ezen belül kb. 90\%-ban PTC-vel kell számolni, mely leginkább a klasszikus formában fordul elö, de follicularis variánsa is gyakori. 10\%ban follicularis pajzsmirigy-carcinoma (FTC) jelentke- 
zik. A Werner-szindróma autoszomális recesszíven öröklődő kórkép. Itt a mutáció a 8. kromoszóma rövid karjának 11-21-es lókuszán (8pll.1-21.1) elhelyezkedő $W R N$-gént érinti. A szindrómára a korai öregedés, az alacsony termet, cataracta, meningeoma, sarcoma jellemző. Pajzsmirigydaganat az esetek 10-18\%-ában jelentkezik. A Werner-szindróma Japánban a leggyakoribb, és a japán betegek esetében a pajzsmirigy érintettsége magasabb (18\%). Jellemzően PTC és FTC alakul ki, de ritkán anaplasztikus pajzsmirigy-carcinomával is számolni kell. A Carney-komplex autoszomális domináns öröklődést mutat. Az érintett gén a PRKARlA, mely a 17. kromoszóma hosszú karjának 22-24-es lókuszán (17q22-24) helyezkedik el. Ebben a kórképben az ajkak, a conjunctiva és a szemzugok foltos bőrpigmentációja mellett számos szerv (például szív, emlő, bőr) myxomája jellemző. Ezekhez schwannomák, valamint mellékvese- és hypophysisadenomák is társulhatnak. Az esetek 60\%-ában található pajzsmirigy göbös elváltozás, melyek nagy része follicularis adenoma; PTC vagy FTC 3\%-ban, fele-fele arányban alakul ki $[2,3,12]$. Mindezek alapján a családi halmozódást mutató differenciált pajzsmirigyrákos betegek esetén a fent részletezett szindrómák részeként megjelenő elváltozások szürése indokolt lehet, különös tekintettel a vastagbél, a vese, az emlö, az endometrium epithelialis tumoraira. Egyes vizsgálatok a melanoma malignum gyakoribb előfordulását is megfigyelték FNMTC esetén [5]. Betegeinkben egyik ismert tumorszindróma klinikai jellegzetességei sem voltak jelen.

Az FNMTC-k 95\%-a nem köthető a fent részletezett tumorszindrómák egyikéhez sem. A szindrómához nem köthető FNMTC első említése 1955-ből származik, amikor Robinson és Orr amerikai sebészek 24 éves, egypetéjü ikerpár esetét mutatták be. Mindkét betegben többszörös nyirokcsomóáttétet adó multifokális papillaris carcinoma igazolódott. Az esetet az is érdekessé teszi, hogy az ikerpár mindkét tagja a szerzők klinikáján (University of Kansas Medical Center) dolgozott ápolónőként, és mútétjükre egymást követő napon került sor [13]. Családi halmozódást mutató, tumorszindrómához nem köthető differenciált pajzsmirigydaganatról tudomásunk szerint ez idáig magyar nyelvű közlés nem jelent meg. Az FNMTC genetikai hátterének megismerésére számos próbálkozás történt, és több hajlamosító eltérést is találtak. Az első lehetséges genetikai változatot $1997-$ ben a 14. kromoszóma hosszú karjának 31-es lókuszán (14q31) találták, melyet MNG1-nek neveztek el, bár akkor még nem találtak szoros kapcsolatot az FNMTC-vel [14]. Ezt követte 1998-ban a TCO (thyroid cell oxyphilia) lókusz felismerése a 19. kromoszóma hosszú karjának 13.2-es lókuszán (19q13.2) [15]. A 2000-es években több kísérlet is történt a betegséggel összefüggésbe hozható lehetséges genetikai eltérések feltérképezésére, de az igazi áttörést a teljesgenom-asszociációs vizsgálat, azaz a GWAS (genome-wide association study) bevezetése hozta meg. Az eljárás során több százezer polimor- fizmus vizsgálatára nyílik lehetőség. Pajzsmirigydaganatokban az első GWAS 2009-ben történt. A módszer segítségével fóleg az európai származásúak körében azonosították többek között a FOXE1 (9q22.33), TITF-1/ NKX2-1 (14q13.3), DIRC3 (2q35), XRCC1 (19q13.31), HABP2 (10q25.3), DICER1 (14q32) géneket. Ezek mellett a fPTC/PRN (1q21), NMTC1 (2q21), FTEN (8p23.1-p22) lókuszokat is leírták mint predilekciós helyeket. A távol-keleti populációkban fóleg a VAV3 (1pl3.3), INSR (19pl3.2), MRSB3 (12q14.3), FHIT (3p14.2), SEPTI1 (4q21.1) és SLC24A6 (12q24.13) géneket azonosították. A legújabb kutatások szerint mikro-RNS-szinten is találtak a betegséghez hozzájáruló lehetséges elváltozásokat. A kicsi, nem kódoló RNS-molekulák számos biológiai folyamatban vesznek részt a mRNS stabilitásának szabályozásával. A PTC-vel kapcsolatos leggyakoribb mikro-RNS-pontmutáció a miR-146a (rs2910164), de ezen kívül több más mikroRNS-polimorfizmust is feltártak. Ezek a miR-608 (rs4919510), miR-933 (rs79402775), valamint a miR149 (rs2292832) [3, 12].

Az FNMTC incidenciája nem ismert pontosan, de az összes NMTC közel 10\%-át teszi ki. Egy nagy, koreai tanulmány szerint 3056, sporadikusnak vélt NMTC-ben szenvedő beteg körében végzett részletes családszürés során a betegek 9,6\%-ának családjában tártak fel jól differenciált pajzsmirigydaganatot [6]. Ez a megállapítás is felhívja a figyelmet az NMTC-s beteg családtagjai szürésének fontosságára. Esetünkben is a testvérpár másik tagja panasz és tünet nélkül jelentkezett, édesanyja és testvére tumoros betegségétől tartva. Az FNMTC-k viselkedését és lefolyását számos tanulmány keretében vizsgálták. Az FNMTC gyakran multifokális, bilaterális, gyakori a tokáttörés, az érinvázió és a regionális nyirokcsomóáttétek előfordulása a sporadikus NMTC-hez képest. Ez az eltérés sokkal inkább nyilvánvaló, ha az FNMTC három vagy annál több családtagot érint, valamint ha a betegek különböző generációhoz tartoznak [6-8]. Néhány szerző nem talált szignifikáns különbséget a familiaris és a sporadikus forma között, de ezen tanulmányokban kisebb a betegszám, kevesebb a vizsgált paraméter, valamint leginkább egy generáción belül és csak két érintett személyt hasonlítottak össze; a többgócúság azonban itt is szignifikánsan magasabb volt a sporadikus formához képest [16-18]. Általánosságban igaz, hogy ha a családon belül csak két személyt érint a betegség, és azon személyek egy generációhoz tartoznak, akkor a betegség lefolyása, viselkedése, megjelenése alig különbözik a sporadikus formáétól. Amennyiben egy családon belül kettőnél több beteg van, különösen ha azok generációs különbséget is mutatnak, akkor egyre agresszívebb viselkedésú daganattal találjuk szembe magunkat $[6,7]$. Esetünkben a szülőnek nyirokcsomóáttét nélküli, egygócú PTC-je volt, míg gyermekeiben már multifokális, tokérintettséggel és többszörös nyirokcsomóáttéttel járó PTC igazolódott. Figyelemre méltó, hogy a második generáció esetén a betegek életkora lé- 


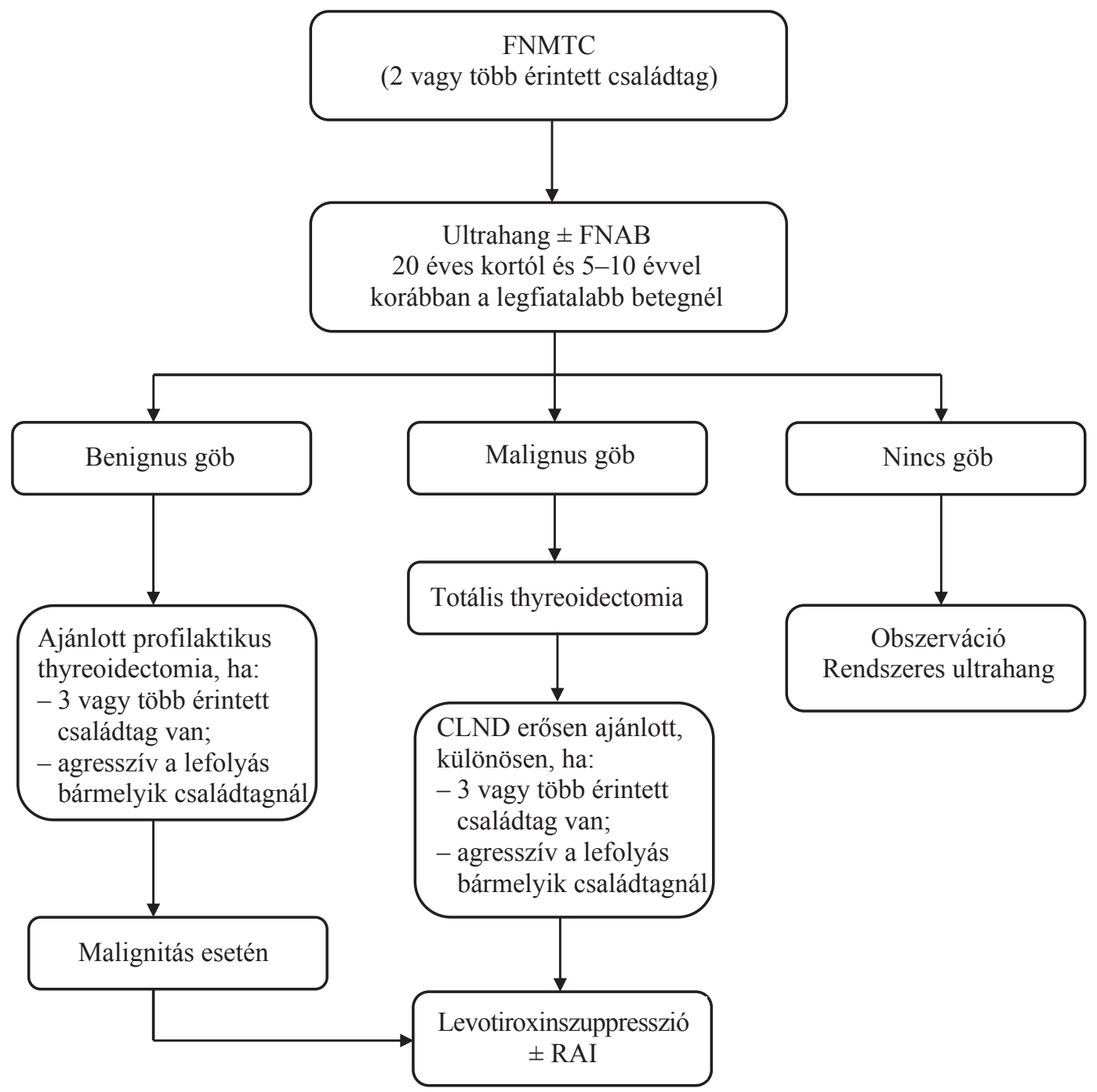

2. ábra

A familiaris nem medullaris pajzsmirigyrák (FNMTC) kivizsgálási és kezelési stratégiája. Mazeh és Sippel javaslata alapján [2]

CLND = központi nyirokcsomó-dissectio; FNAB = aspirációs vékonytú-biopszia; FNMTC $=$ familiaris nem medullaris pajzsmirigyrák; RAI = radiojód-terápia

nyegesen alacsonyabb, ami csak részben magyarázható a korai szúrés alkalmazásával. A második generációban a női dominancia megmarad, de a férfi betegek száma emelkedik. A több generációt és kettőnél több beteg személyt érintő FNMTC esetében a betegségmentes túlélés jelentősen rövidebb a sporadikus NMTC-hez képest [7-9].

Mindezeket figyelembe véve az FNMTC kivizsgálása, kezelése és követése más stratégiát igényel, mint a sporadikus, jól differenciált pajzsmirigyrákoké. Az érvényes II.C szintü ajánlást a 2. ábrán mutatjuk be. Elsősorban a családszürés fontosságát kell kiemelni. Kettő vagy több családtagot érintő NMTC esetén az összes családtagot vizsgálni kell, ami első lépésben ultrahangvizsgálatot jelent. Az első ultrahangvizsgálatot 20 éves korban kell elvégezni, vagy ha ennél fiatalabb érintett családtag ismert, úgy a legfiatalabb érintett személy koránál 5-10 évvel fiatalabb korban. Ha göb nincs, évenkénti ultra- hangkontroll javasolt. Citológiailag benignus göb(ök) esetén szoros ultrahangkontroll javasolt, de amennyiben három vagy több családtagot érint a betegség, vagy valamelyik érintett személy tumora agresszív, úgy megfontolandó a profilaktikus thyreoidectomia. FNAB-vel malignus elváltozás esetén a teljes pajzsmirigy-eltávolítás az elfogadott kezelés, centrális nyaki blokkdissectióval, radiojód-terápiával és levotiroxinszuppressziós kezeléssel [2]. Esetünkben is mindkét gyermeken ezt a kezelési stratégiát alkalmaztuk. Mivel az FNMTC kiújulási hajlama sokkal nagyobb a sporadikus formáénál, a TSH megfelelően alacsony szinten való tartása hosszabb ideig javasolható e betegség utókezelésében [8].

Esetünkkel szeretnénk felhívni a figyelmet a családi halmozódást mutató, jól differenciált pajzsmirigydaganatok jelenlétére, azok agresszívebb voltára, és emiatt a családszưrésnek, valamint a kezelési stratégia megválasztásának fontosságára. 
Anyagi támogatás: A közlemény megírása anyagi támogatásban nem részesült.

Szerzôi munkamegosztás: T. G.: Beteg kivizsgálása, adatok gyújtése, irodalomkutatás, a kézirat megszövegezése. N. V. E.: A kézirat revíziója. Gy. F.: Beteg kivizsgálása, kezelése, a kézirat revíziója. B. M.: Beteg kivizsgálása, kezelése. M. Cs.: Beteg vizsgálata. A közlemény végleges változatát valamennyi szerző elolvasta és jóváhagyta.

Érdekeltségek: A szerzőknek nincsenek érdekeltségeik.

\section{Irodalom}

[1] Konrády A. Differentiated thyroid cancer. In: Leövey A, Nagy VE, Paragh Gy, et al. (eds.) Handbook of endocrine and metabolic diseases. [Differenciált pajzsmirigy-carcinoma. In: Leövey A, Nagy VE, Paragh Gy, et al. (szerk.) Az endokrin és anyagcsere-betegségek gyakorlati kézikönyve.] Medicina Kiadó, Budapest; 2017; pp. 203-211. [Hungarian]

[2] Mazeh H, Sippel RS. Familial nonmedullary thyroid carcinoma. Thyroid 2013; 23: 1049-1056.

[3] Peiling Yang S, Ngeow J. Familial non-medullary thyroid cancer: unraveling the genetic maze. Endocr Relat Cancer 2016; 23: R577-R595.

[4] Bychkov A. Thyroid gland general. WHO classification. PathologyOutlines.com, Inc. http://www.pathologyoutlines.com/topic/thyroidwho.html [accessed: April 29, 2020].

[5] Hemminki K, Eng C, Chen B. Familial risk for nonmedullary thyroid cancer. J Clin Endocrinol Metab. 2005; 90: 5747-5753.

[6] Park YJ, Ahn HY, Choi HS, et al. The long-term outcomes of the second generation of familial nonmedullary thyroid carcinoma are more agressive than sporadic cases. Thyroid 2012; 22 356-362.

[7] Capezzone M, Marchisotta S, Cantara S, et al. Familial non medullary thyroid carcinoma displays the features of clinical anticipation suggestive of a distinct biological entity. Endocr Relat Cancer 2008; 15: 1075-1081.
[8] Zhang YB, Wang XX, Zhang XW, et al. Familial nonmedullary thyroid carcinoma: a retrospective analysis of 117 families. Chin Med J (Engl). 2018; 131: 395-401.

[9] Mazeh H, Benavidez J, Poehls JL, et al. In patients with thyroid cancer of follicular cell origin, a family history of nonmedullary thyroid cancer in one first-degree relative is associated with more aggressive disease. Thyroid 2012; 22: 3-8.

[10] Morris LG, Tuttle RM, Davies L. Changing trends in the incidence of thyroid cancer in the United States. JAMA Otoralyngol Head Neck Surg. 2016; 142: 709-711.

[11] Bray F, Ferlay J, Soerjomataram I, et al. Global cancer statistics 2018: GLOBOCAN estimates of incidence and mortality worldwide for 36 cancers in 185 countries. CA A Cancer J Clin. 2018; 68: 394-424. [Erratum: CA A Cancer J Clin. 2020; 70: 313.]

[12] Hińcza K, Kowalik A, Kowalska A. Current knowledge of germline genetic risk factors for the development of non-medullary thyroid cancer. Genes 2019; 10: 482.

[13] Robinson D, Orr T. Carcinoma of the thyroid and other diseases of the thyroid in identical twins. AMA Arch Surg. 1955; 70: 923-928.

[14] Bignell GR, Canzian F, Shayeghi M, et al. Familial nontoxic multinodular thyroid goiter locus maps to chromosome $14 \mathrm{q}$ but does not account for familial nonmedullary thyroid cancer. Am J Hum Genet. 1997; 61: 1123-1130.

[15] Canzian F, Amati P, Harach HR, et al. A gene predisposing to familial thyroid tumors with cell oxyphilia maps to chromosome 19p13.2. Am J Hum Genet. 1998; 63: 1743-1748.

[16] Robenshtok E, Tzvetov G, Grozinsky-Glasberg S, et al. Clinical characteristics and outcome of familial nonmedullary thyroid cancer: a retrospective controlled study. Thyroid 2011; 21: 4348.

[17] Maxwell EL, Hall FT, Freeman JL. Familial nonmedullary thyroid cancer: a matched-case control study. Laryngoscope 2004; 114: 2182-2186

[18] Ito Y, Kakudo K, Hirokawa M, et al. Biological behavior and prognosis of familial papillary thyroid carcinoma. Surgery 2009; 145: 100-105.

(Tóth Géza dr., Salgótarján, Füleki út 54-56., 3100 e-mail: gezatothdr@gmail.com)

\section{"Omnia domi nascuntur." (Minden jó vagy rossz a családi házból ered.)}

\footnotetext{
A cikk a Creative Commons Attribution 4.0 International License (https://creativecommons.org/licenses/by-nc/4.0/) feltételei szerint publikált Open Access közlemény, melynek szellemében a cikk bármilyen médiumban szabadon felhasználható, megosztható és újraközölhető, feltéve, hogy az eredeti szerző és a közlés helye, illetve a CC License linkje és az esetlegesen végrehajtott módositások feltüntetésre kerülnek.
} 